\title{
研究論文
}

南極における超伝導重力計の設置とその除震及び監視技術の開発

\author{
池田 博 ${ }^{\dagger}$, 土井浩一郎*1, 福田 洋一*2, 野口 隆志*3, \\ 中嶋 俊哉*4, 飯村 憲*4, 渋谷 和雄*1
}

\section{Installation of a Superconducting Gravimeter in Antarctica and Development of Its Vibration-isolating Mechanism and Remote Monitoring System}

\author{
Hiroshi IKEDA ${ }^{\dagger}$, Kouichirou DOI*1 ${ }^{* 1}$ Youichi FUKUDA*2, Takashi NOGUCHI*3, \\ Toshiya NAKASHIMA ${ }^{* 4}$, Ken IIMURA*4 and Kazuo SHIBUYA*1
}

\begin{abstract}
Synopsis: From February 2003 to January 2004, a new superconducting gravimeter with a cryocooler was installed to replace the former device at the Syowa station in Antarctica. The new gravimeter has a high sensitivity of one nano-gal and is being used to survey the earth's core in the Global Geodynamics Project. A new type of diaphragm was confirmed to well isolate the vibration from the refrigerator cold-head and effectively prevent solid air contamination. A remote monitoring system from Japan is also going to be installed.
\end{abstract}

Keywords: superconducting gravimeter, GM refrigerator, diaphragm, monitoring system, Antarctica

\section{1. はじめに}

重力測定の方法には大別して重力の絶対值を測定する絶 対重力測定と、重力の時間的な変化を測定する相対重力測 定の 2 つがある。絶対重力計としては FG5（米国 Micro-G 社製) が代表的で最近になって $2 \mu \mathrm{Gal}$ の測定感度が得られ るようになってきた ${ }^{1)}$ 。一方、相対重力計としてはスプリ ング式のもので可搬可能なラコスト重力計やシントレック ス重力計がある ${ }^{2)}$ 。しかしスプリング式はスプリングの劣 化という欠点を持っており感度も数 $10 \mu \mathrm{Gal}$ が限界であ

Received June 15, 2004

筑波大学研究基盤総合センター低温部門

干305-8577 茨城県つくば市天王台 1-1-1

Cryogenic Division Research Facility Center University of

Tsukuba, 1-1-1 Tenoudai, Tsukuba, Ibaraki 305-8577, Japan

${ }^{* 1}$ 国立極地研究所

干173-8515 東京都板橋区加賀 1 丁目 9-10

National Institute of Polar Research, 1-9-10 Kaga, Itabashi-ku,

Tokyo 173-8515, Japan

*2 京都大学大学院理学研究科

干606-8502 京都府京都市左京区追分町北白川

Department of Geophysics, Graduate School of Science, Kyoto

University, Kitashirakawa Oiwake-cho, Sakyo-ku, Kyoto 606-8502, Japan

*3 池上技術

干263-0043 千葉県千葉市稲毛区小仲台 8-22-3-306

Ikegami Technology, 8-22-3-306 Konakadai, Inage-ku, Chiba 263-0043 Japan

*4 日本酸素株式会社

干212-8509 神奈川県川崎市幸区塚越 4 丁目 320-1

Nippon Sanso Corporation, 4-301-1 Tsukakoshi, Saiwai-ku,

Kawasaki, Kanagawa 212-8509 Japan

† E-mail:ikeda@bk.tsukuba.ac.jp
る。そこで 1980 年代後半に米国 GWR 社より超伝導重力計 が開発された ${ }^{3)}$ 。超伝導重力計はマイスナー効果を利用し て絶対重力計よりも 3 桁も感度の高い $1 \mathrm{nGal}$ の測定が可能 である。しかし、久点として超伝導重力計は相対重力計で あるため絶対值の校正を行う必要がある。

南極昭和基地では1993年3 月から世界に先駆けて超伝導 重力計による重力変化の連続観測を開始し 2004 年 5 月現在 なお南極大陸で唯一超伝導重力計の観測を継続している。 筆者の池田が参加した第 44 次南極地域観測隊地学部門で は2003 年 2 月より 2 代目の新型超伝導重力計の設置を開始 した。

本稿では新規に $4 \mathrm{~K}-\mathrm{GM}$ 冷凍機を付属した新超伝導重力 計装置の立上げ ${ }^{4)}$ と 4K-GM 冷凍機と重力計間の除震対策 及び空気などの不純物混入対策として新ダイアフラムの開 発と南極昭和基地に設置してある超伝導重力計のデータを 日本から直接監視するシステムの開発について報告する。

\section{2. 超伝導重力計の概要}

本装置は米国 GWR 社の製品である ${ }^{3)}$ 。超伝導重力計の 動作原理は、球形の超伝導体 (中空の $\mathrm{Cu}$ 球に $\mathrm{Nb}$ を蒸着し た物)をマイスナー効果で浮上させ、それが受ける重力変化 に依存した位置変化を補正する制御電流を検出する。それ を換算して設置場所の重力相対変化とするもので従来のバ ネ式の重力計に比べ 3 桁もの感度向上と絶対重力計では実 現できない極めて長期間の安定した連続観測が可能であ る。昭和基地での測定感度は 0.6〜 $1.0 \mathrm{nGal}$ を実現し、これ までに地球自由振動（周期数分）から極運動（周期 1 年以 


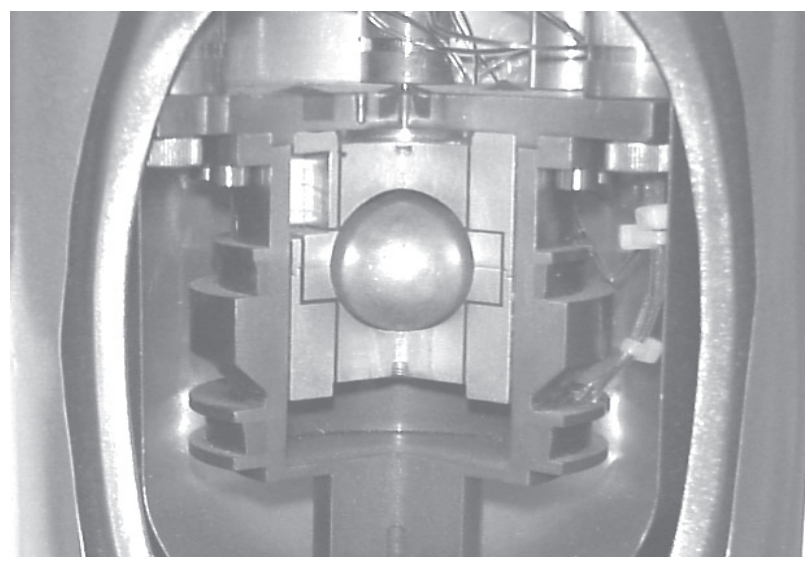

Fig. 1 Cross-sectional view of a superconducting gravimeter sensor model.

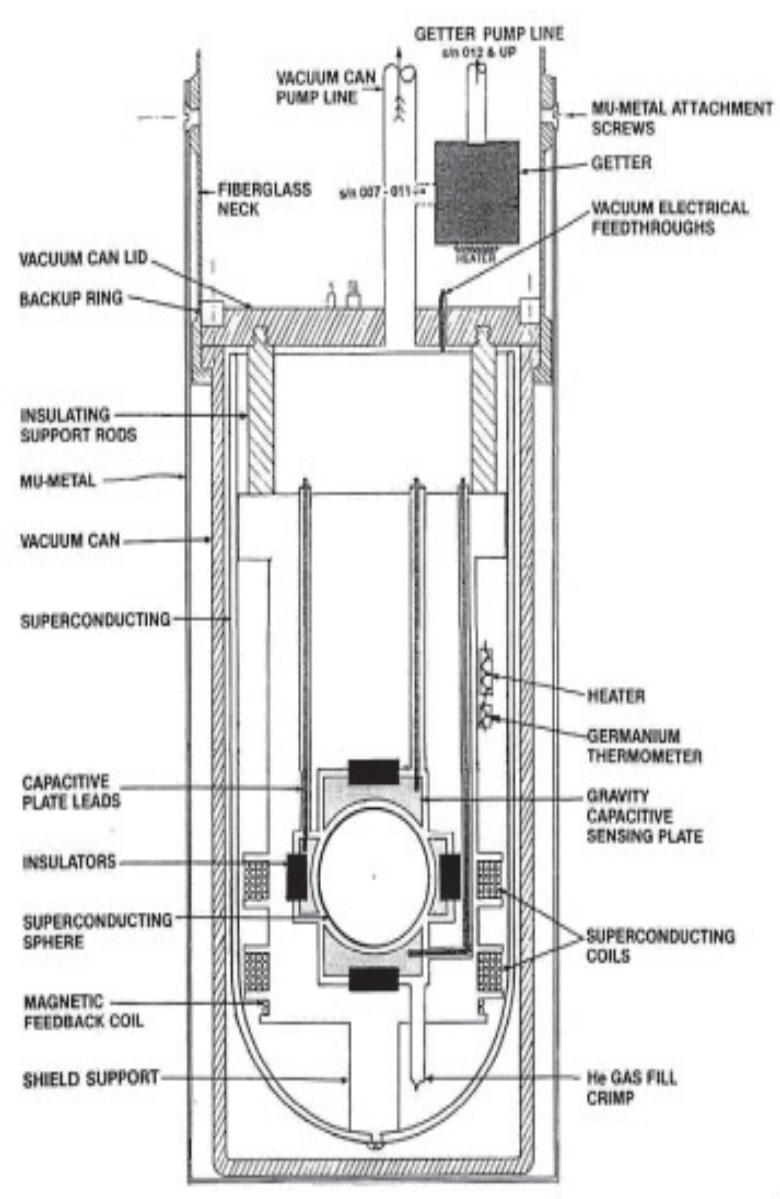

Fig. 2 Gravity-sensing unit inside the Dewar vessel.

上）にいたる広い帯域における様々な現象に起因する重力 変化が観測されており、昭和基地の超伝導重力計の観測デ ータによって常時地球自由振動などの新現象の発見に寄与 している5)。

今後、新しく設置した新超伝導重力計によって地球内部 に起因する重力変化や地殼変動に伴う重力の変化をより高 い感度で検出することが期待されている。
Table 1 Specifications of the refrigerator and Dewar vessel.

\begin{tabular}{|l|l|}
\hline \multirow{2}{*}{$\begin{array}{l}\text { GM refrigerator } \\
\text { (Leybold } 4.2 \mathrm{~K} \mathrm{Lab})\end{array}$} & $\begin{array}{l}\text { Compressor (air-cooling): } \\
\text { CTI M8200, } 2.1 \mathrm{~kW}, 60 \mathrm{~Hz}\end{array}$ \\
\cline { 2 - 2 } & $1^{\text {st }}$ stage: $4 \mathrm{~W}$ at $60 \mathrm{~K}$ \\
\cline { 2 - 2 } & $2^{\text {nd }}$ stage: $0.25 \mathrm{~W}$ at $4.2 \mathrm{~K}$ \\
\hline Helium Dewar vessel & Volume capacity: $30 \mathrm{~L}$ \\
\hline
\end{tabular}

\section{3. 構造および性能諸元}

新超伝導重力計の重力変化感知部のカットモデルとセン サーユニット概略図を Fig. 1 と Fig. 2 に示す。Fig. 2 に示す ように中空ニオブ球の浮上体はその位置を決める 4 つの静 電容量プレートに覆われ真空容器内に置かれている。真空 容器内には、浮上位置制御のための永久電流型コイルが 2 個あり下部コイルはニオブ球の浮上させるのに用い、上部 コイルは超伝導重力計として運用するために極めて重要な 役割を果たす。つまり、上下コイルの作る磁場によって磁 場勾配を極力弱め重力計としての感度を上げるようになっ ている。その他に位置変化制御用コイルが 1 個置かれてい る。外部磁場の影響を切るための超伝導シールドが浮上機 構全体を覆うように配置され、これらを内蔵する真空容器 はさらに磁気シールドのために $\mu$ メルで覆われている。

Fig. 2 に示すセンサーユニットはアルミ製液体ヘリウムデ ユワー (内容量 30 リットル) に固定されていて浸漬冷却さ れる。またデュワーネック部には 1 代目の超伝導重力計用 では液体ヘリウムの蒸発を抑制するための $10 \mathrm{~K}-\mathrm{GM}$ 冷凍機 が挿入されていたが、10K 冷凍機では液体へリウムの蒸発 を抑えることができるがへリウム液面の低下は避けられな い。そこで新超伝導重力計では $10 \mathrm{~K}$ 冷凍機とは異なり、 4K-GM 冷凍機が挿入されるようになっており、冷凍機単体 によって液体へリウムの液化が可能であり、液面制御もで きるようになっている。そのためへリウム容器も小型化さ れ今まで 200 リットル容器を使用していたが今回は30リッ トル容器となった。最大の利点は地学担当越冬隊員の大き な負担となっていた半年に 1 回行っていたへリウム液化運 転作業が不要になり液体へリウムのトランスファー作業も 無くなり担当隊員の負担が大幅に軽減された。

南極昭和基地という設置場所の特異性から、本機は初期 予泠に、液体窒素、液体ヘリウムを使用せずに常温から 4K-GM 冷凍機のみで冷却できるように設計されているが 今回の初期冷却では液体窒素による予泠を行った。さらに 長期連続計測が可能なように冷凍機の冷凍出力はコール ドヘッドの回転数可変機構により制御できるようになっ ている。冷凍機は Leybold 社の 4.2K-1/4W GM 型を用いて おり冷凍機とへリウム容器の仕様を Table 1 に示す。圧縮 機はこれまで水冷式の圧縮機が使用されていたが水のト ラブルが多かったので空冷式を使用することとした。 


\section{4. 装置の設置と初期冷却}

新超伝導重力計は日本から 1 ケ月半の荒波（特に南緯 40 度から 60 度の低気圧の墓場と呼ばれる暴風圈)を航海して 砕水艦「しらせ」より 2002 年 12 月 27 日に昭和基地の重力 計室に搬入された。開梱後、真空引きを開始した。日本か ら昭和基地まで 1 万 4000 キロに及ぶ輸送で心配された断熱 真空槽の真空劣化は $72 \mathrm{~Pa}$ の圧力上昇で収まり輸送による 断熱容器のダメージは室温状態では無かった。輸送による 断熱真空槽のダメージを防ぐため超伝導重力計に 2 重のシ ヨックアブソーバを組込み、「しらせ」船倉では厳重に捕 縛し、昭和基地到着後は慎重に輸送したことが有効であっ た。その後、ターボポンプによって 1 ケ月間掛けて断熱真 空槽の真空引きを行った。その間に梱包された圧縮機、UPS 装置や測定器を開梱して組み立て作業を行った。最終的に 断熱真空槽の真空度は $2.2 \times 10^{-3} \mathrm{~Pa}$ で真空バルブを閉とし た。

越冬交代後の 2 月 1 日より初期冷却作業を開始した。2 月 5 日にへリウム容器内を予冷していた液体窒素を追出し 後、昭和基地の設置されていたへリウム液化機（液化能力 1 リットル/毎時) によって液体ヘリウムを製造し液体へリ ウムによる予冷を開始した。予冷では超伝導センサーを急 激に冷やさないために 3 時間以上掛けて液体へリウムのト ランスファーを行った。30リットル容器に液体へリウムを 24\%まで溜めることができた。翌日から 4K-GM 冷凍機を 液化運転モードにして連続運転を開始した。液体窒素の予 冷、追出し、液体へリウムによる初期冷却過程の様子は我々 が開発し新たに設置した重力計監視システムでモニターし た。それにより得られた初期冷却曲線を Fig. 3 に示す。図 中、赤は容器ネック上部（冷凍機 1 段近傍）で青がネック 下部（冷凍機 2 段近傍）で緑が容器底部の温度を示してい る。最初は容器内に液体窒素があるため緑の容器底部が 77 $\mathrm{K}$ を示している。その後、液体窒素が追出されて容器底部 の温度は上昇してその後 3 時間ほどかけて液体へリウム温 度へ緩やかな冷却曲線を示している。2 月 6 日に $4 \mathrm{~K}-\mathrm{GM}$ 冷 凍機の運転を開始して連続運転状態で 3 月 17 日までに液体 ヘリウム液面が $88 \%$ となった。その間、液面の位置により 容器内で若干の熱振動も発生したが液面が $70 \%$ を超えた ころから熱振動の発生は急激に弱まった。このことから連 続運転時のへリウム液面は $70 \%$ 以上で運転するように冷 凍機回転数の調整を行った。十分な液体へリウムが得られ たので 3 月 18 日に $\mathrm{Nb}$ 球の上下にある超伝導コイルにパル ス電流を流して調整することにより初期レビテーションを 試夕新超伝導重力計の $\mathrm{Nb}$ 球が初めて浮上に成功した。そ の後、重力測定の感度を決めている Fig. 2 で示した $\mathrm{Nb}$ 球 の位置調整を下部と上部の超伝導コイルに流す微小電流調 整によって位置調整を慎重に行い測定感度の向上調整を重 ね、また正しい重力測定には $\mathrm{Nb}$ 球が鉛直線方向に作動し

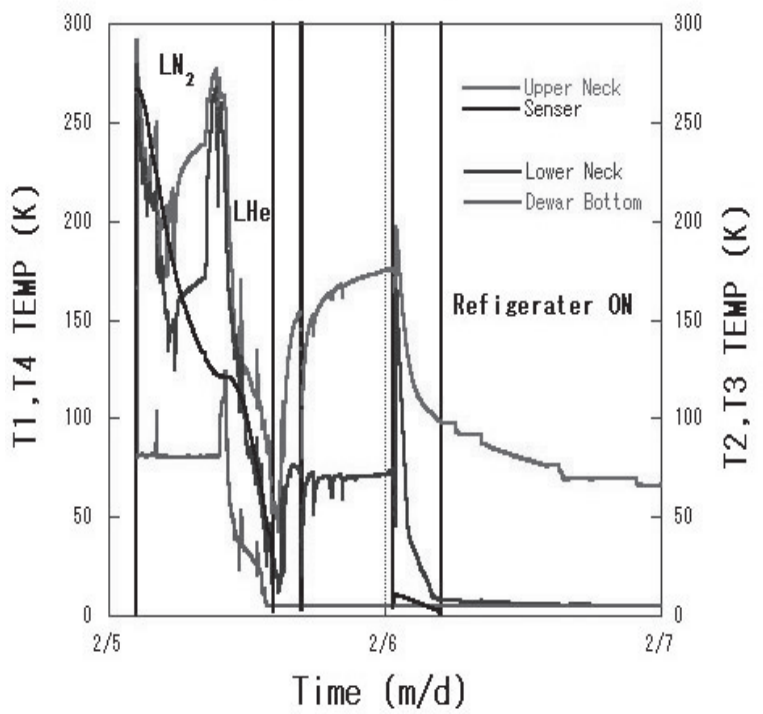

Fig. 3 Initial cool-down curve.

なければならないので傾斜補正のために左右のマイクロメ ーターの調整を行った。最終的に 4 月 18 日より新超伝導重 力測定のデータ収録を開始した。

\section{5. 新超伝導重力計の静特性}

5 月 14 日より $4 \mathrm{~K}-\mathrm{GM}$ 冷凍機停止状態での新超伝導重力 計単体での性能試験を行った結果、従来の超伝導重力計よ りも $\mathrm{Nb}$ 球の位置調整がフィードバック回路により微小電 流の制御が精密にできたため観測された潮汐データの周波 数解析結果より感度が 1 桁以上向上していることが確認で きた。

さらに Fig. 4 に示すように越冬中に生じる可能性のある トラブル対策として予備 4K-GM 冷凍機の性能確認試験を 行った。図からも分かるように冷凍機停止状態ではネック 上部の温度は $210 \mathrm{~K}$ 程度で安定になりネック下部の温度は $160 \mathrm{~K}$ 程度で安定した。一方、運転状態ではネック上部の 温度が $55 \mathrm{~K}$ 程度で、ネック下部は液体へリウム温度になっ た。4K-GM 冷凍機の性能としては、連続運転による液体へ リウムの製造量はへリウム容器容量に換算して 1 台で $3 \% /$ 日、2 台で $6 \% /$ 日の性能であった。

新超伝導重力計と旧超伝導重力計（Fig. 5) との並行観測 を 5 月から 11 月まで 6 ケ月間行い相互のデータを比較し た。図で右側が新超伝導重力計で左側の青くて大きいへリ ウム容器が旧超伝導重力計である。真ん中の銀色のクライ オスタットがヘリウム液化機である。新旧超伝導重力計の 青いヘリウム容器の大きさの違い（200リットルと 30 リッ トル）が判断できると思う。並行観測は 11 月 6 日で終了し 新超伝導重力計単体での観測に移行した。12月 28 日から は第 45 次隊の福田・土井・平岡らによって夏作業で持ち込 まれた絶対重力計の $\mathrm{FG}^{11}$ によって相対重力計である新超 伝導重力計の絶対值校正を 1 ケ月間に亘って行った。 


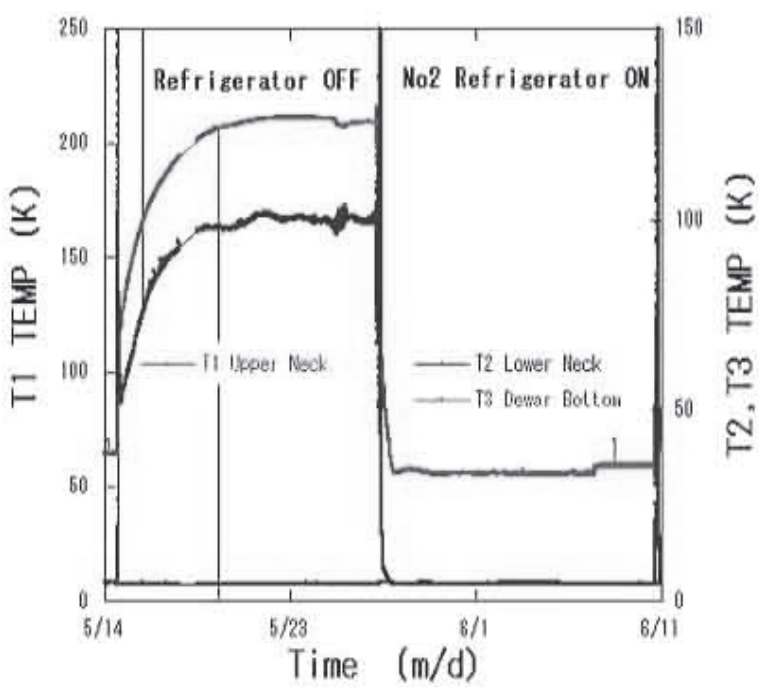

Fig. 4 Cooling test curve of the backup refrigerator.

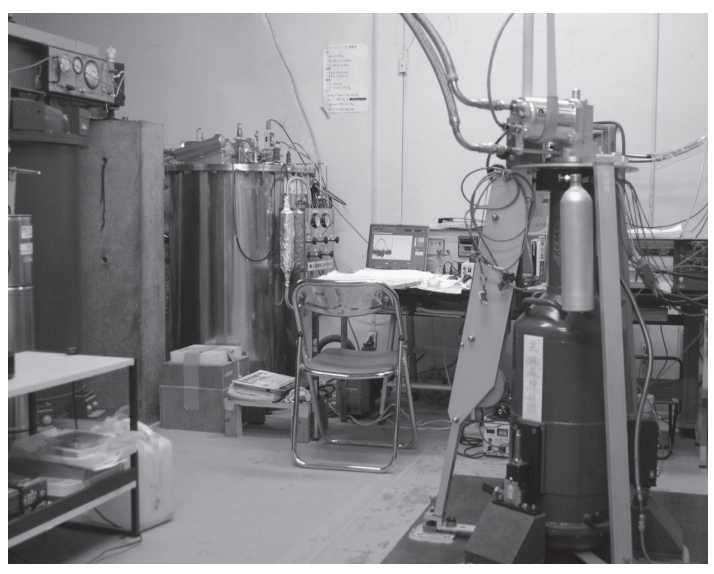

Fig. 5 New superconducting gravimeter (right side) and old gravimeter (left side).

\section{6. 冷凍機と容器間の除震対策と不純物混入対策}

新超伝導重力計の構成図を Fig. 6 に示す。ここでは計測 系の機器は省略されているが図で示すように超伝導重力計 センサーは液体へリウム容器内に収められている。右側の 圧縮機は $4 \mathrm{~K}-\mathrm{GM}$ 冷凍機用の空冷圧縮機である。フレキシブ ルホースによって冷凍機と接合されており冷凍機のコール ドヘッドはへリウム容器上部フランジよりヘリウム容器内 に挿入できるようになっている。それにより 4K-GM 冷凍 機が作動し容器内を常に液体へリウム温度に維持すること ができるようになっている。

ここで重要な問題はへリウムガスが圧縮機から吐出され 冷凍機でピストンを作動させるため振動が発生することで ある。冷凍機の振動は超伝導重力センサーへのノイズ源と なりセンサーの感度に悪影響を与えるため極力避けなけれ ばならない。そこで泠凍機と容器の間には、図で Isolating diaphragm と書いたところから矢印の拡大図で示すような
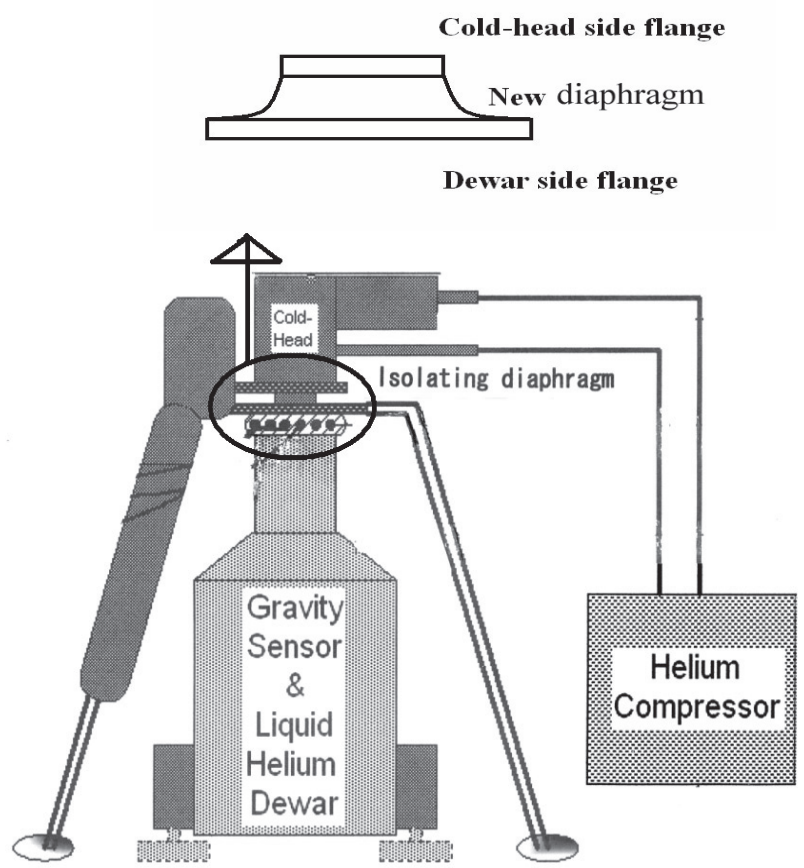

Fig.6 Component of a new superconducting gravimeter.

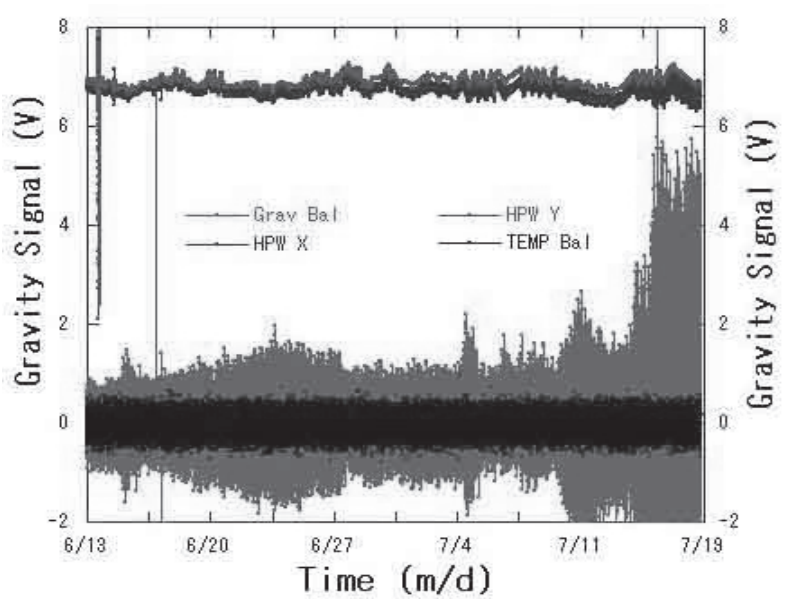

Fig. 7 Gravity balance signals affected by the vibrations of the cold-head.

コールドヘッドとヘリウム容器間に、従来からゴム製隔膜 (ダイアフラム) が緩衝材として使用されている。このダ イアフラムの最大の目的は冷凍機から発生する振動をへリ ウム容器のセンサーに極力伝えないようにする除震の役目 を果たことである。そして、もうひとつの重要な役目は不 純物混入の防止である。しかし、従来のゴム製ダイアフラ ムでは除震についてはある程度効果はあるが不純物混入防 止策としては空気やへリウムガスが透過する問題は解決さ れていない。つまり、ゴムの性質上、室温ではゴム本体か ら空気やへリウムガスの透過が起こり冷凍機を長期間運転 していると冷凍機のネック部に不純物混入により固体空気 の成長が起きてしまう。冷凍機のコールドヘッドと容器壁 面の間に成長した固体空気を通じて冷凍機の振動がセンサ 


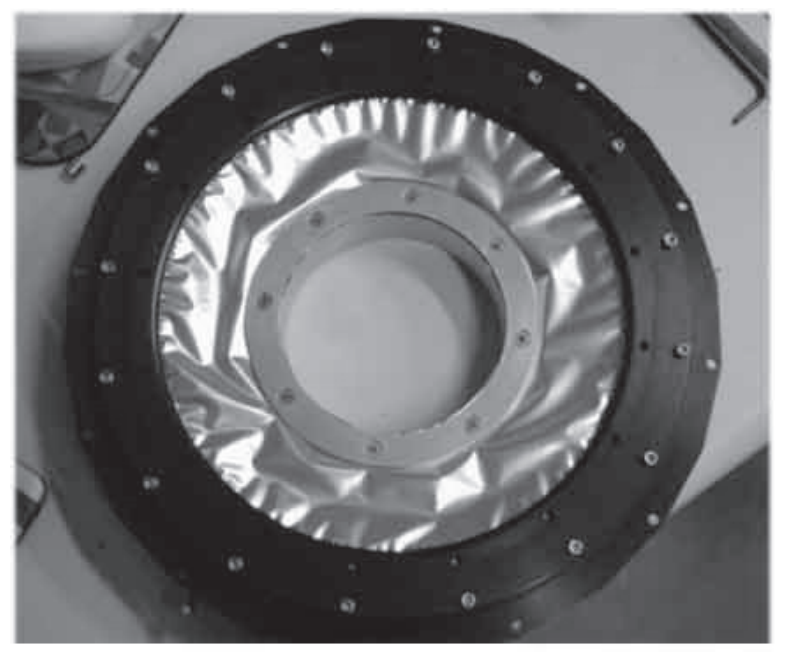

Fig. 8 New type of Al-coated polyurethane diaphragm to prevent vibrations and solid-air contamination.

一に伝わるため、これがノイズとなり観測精度の低下を招 いてしまう。今回も当初は従来のゴム製ダイアフラムを使 用していたため連続運転を開始してから 2 ケ月ぼ経過し た 7 月 13 日ごろから Fig. 7 に示すように赤色で示した Gravity Balance 信号に冷凍機の振動が伝わって生じるノイ ズ信号が増大寸る現象が顕著に観測されるようになった。 そのノイズ信号は通常の 5 倍以上の電圧值を示した。そこ で確認のために 4K-GM 冷凍機をへリウム容器から引き抜 いてみるとへリウム容器壁面と冷凍機コールドヘッドの円 周上に固体空気が成長しているのが確認できた。そこで 我々は超伝導重力計の連続運転を左右するこれらの問題の 解決策として今までに無い新しいダイアフラムとして Fig. 8 に示すような透過や強度の面で問題のあった従来のゴム 製ダイアフラムに代えて両面にアルミ蒸着を施したポリウ レタン製のダイアフラム（ゴムのへリウム透過率に比べて $1 / 1000$ の割合に低下させ効果がある $\left.{ }^{6)}\right)$ を導入して試験を 試みた。Fig. 8 で銀色に光っているのが両面蒸着されたポ リウレタン製ダイアフラムで内側がヘリウム容器側に固定 され、外側が冷凍機を乗せるフランジに固定される。作業 はゴム製ダイアフラムと同じサイズにアルミ蒸着ポリウレ タンをカット後、厚みが $70 \mu \mathrm{m}$ と薄いためネジ部に挟みし ろを取付けて冷凍機架台とへリウム容器の間に組み込み六 角ボルトで両側に取付ける。取付け後、リークテストを行 いヘリウム容器からのへリウムガスの漏れが無いことを確 認した。その結果、連続運転開始後 2 ケ月後に冷凍機をへ リウム容器から引き上げてみたが固体空気は成長しておら ず、また Gravity Balance 信号に顕著なノイズ信号も観測さ れていない。現在、我々が導入した新しいダイアフラムを 設置後、連続運転 5 ケ月 (2004 年 6 月時点) が経過している が順調に観測を継続し稼動している。そのため安定した観 測データが得られている。

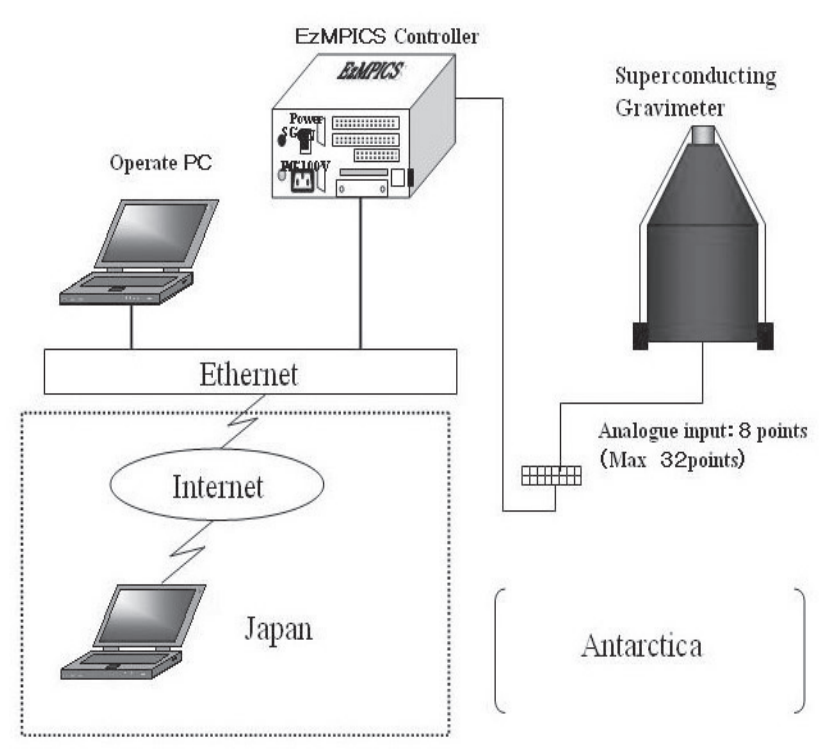

Fig. 9 Block diagram of the EzMPICS controller system and remote computer operation from Japan.

この対策技術は今後、振動及び不純物混入を極力抑えた い他の冷凍機冷却装置にも広く応用可能である。

\section{7. 日本からの重力計監視システムの構築}

南極昭和基地という設置場所の特異性から、第 44 次観 測隊までは国内と南極昭和基地の交信はインマルサット衛 星による通信で $64 \mathrm{kbps}$ の速度のため 3 時間に 1 度の通信 のみ可能であった。また、電子メールのサービスのみでイ ンターネットへの接続はできなかった。しかし第 45 次観 測隊によりインテルサット衛星に送受信できるアンテナが 設置されたことにより通信速度は飛躍的に改善され 1 Mbpsの通信速度が可能となり常時接続も可能となった。そ こで超伝導重力計の運転状態や観測データを日本から直接 監視できるようなネットワークコンピュータを第 44 次越 冬隊で昭和基地に持ち込み、装置立上げ時に組み込んだ。 これにより Fig. 9 に示すように我々が開発した EzMPICS ${ }^{7)}$ を介して日本から南極昭和基地の重力計室で稼動している 新超伝導重力計に直接アクセスできるようになった。現在、 VPN (Virtual Private Network)によるセキュリティーの申請 も含めて準備を進めているが、いずれ Fig. 4 や Fig. 7 に示 すような超伝導重力計の冷却状態や Gravity Balance 信号 などの運転状況・観測データを日本に居ながらにして監視 できる予定である。

\section{8. まとめ}

4K-GM 冷凍機を取付けた新超伝導重力計を南極昭和基 地重力計室で立上げた。今まで担当隊員にとって半年に 1 度必ず必要だったヘリウム液化運転を行う必要が無くな り、負担が大幅に軽減された。さらに新超伝導重力計は 